УДК 159.9.07(072)

doi: $10.15330 /$ ps.10.1.152-159

\author{
Jevhen Karpenko \\ Vasyl Stefanyk PreCarpathian National University \\ psiholog_pp@ukr.net
}

Rafal Abramciow

The Pedagogical University of Cracow named after the Commission of National Education abramciow@gmail.com

\title{
THE PROBLEM OF QUALITATIVE METHODS APPLICABLE IN THE PSYCHOLOGY OF PERSONALITY
}

\begin{abstract}
The article argues the historical confrontation and the mutual additions of qualitative and quantitative methods in psychology, and it presents the important systematized methodological aspects as for the application of qualitative methods in personality psychology. These aspects are: substantiation of qualitative research as the most appropriate methodology for the holistic study of a person as a personality from the standpoint of the systematic approach; combination of the diagnostics and psychological influences during dialogic interactions of a psychologist-researcher and a psychologist-practitioner (as two roles of one person) with a client in a psychotechnical situation; the characteristic features of qualitative research (holism, identified meanings and their interpretations, contextuality, reflexivity, interactivity, absence of directives, inductive approach to data, correspondence to situations, attention to individual cases, etc.); the types of qualitative studies - diagnostic, exploitative, verificatory or exploitative-verificatory - and variants of their combination; classification of methodological approaches that help chose certain qualitative methods based on their philosophical foundations, research purpose and objects, cognition principles and technologies; the methodological principles of qualitative research - conceptual sensitivity, interpretive reconstruction, reflexivity; the validity criteria for qualitative methods with taking into account a research stage (a level in the structure) - planning and data collecting, their analysis, data interpretation and presentation, ethical validity - and the structure of a final scientific work prepared by the research results (requirements for introduction, literature review and theoretical analysis, an empirical part, conclusions, possible applications). The conclusion is made about the relevance of qualitative researches at the modern meta-modern stage of the psychological science on personality.
\end{abstract}

Keywords: methodology, personality psychology, qualitative methods (research), validity of qualitative research, meta-modern.

Problem challenge. The modern science at the verge of the meta-modernism epoch brings to a new level the long-time discussed issues of links between different methodological foundations for research on the psychology of personality. According to Z. Karpenko, the historical confrontation exists between the natural-scientific and humanitarian paradigms. The first paradigm looks at a human being as a being determined by external (situational) or internal (belonging to the organism) factors, so general patterns of functioning and development can be understood by objective research and experiments. The second one looks at a person as a unique spiritual being, capable to self-development and self-transcendence and choosing values-oriented behaviour [5, p. 172].

The confrontation between these paradigms gives rise to the derivative parallelism: the nomothetic approach against the idiographic one. The first approach proposes a set of methods focused on general patterns and universal mechanisms of personal development and formation, and the second one covers a set of methods focused on the description of a person as a unique individuality.

Hence another parallelism exists, noted by V. Dilthey [3], in his time: the explanatory psychology as a science, which uses the methods of natural sciences to study the psyche with the purpose to decompose it into «the primary elements» and to determine functional, cause-andeffect relations between the singled out elements, and the descriptive psychology, which subject is understanding of an individual's mental life in its integrity, uniqueness and value-semantic content. 
The logical continuation of these parallels is the juxtaposition of two methods: the socalled objective method, which means study of the psyche through observation over behaviour, organization of experiments, testing, etc., and the subjective method of direct studies of the psyche through self-observation of human mental states and identification and empathy with other people, etc.

The derivatives of these opposing approaches is a choice of the $\mathrm{R}$ - methodology (quantitative analysis, statistical methods) or $\mathrm{Q}-$ methodology (qualitative analysis, hermeneutical procedures) [5, p. 172-173].

The main applicable areas for quantitative and qualitative research methods are discussed by V. M. Druzhinin, who builds the level hierarchy of mental systems [4, p. 281-284]:

1. Zero level. It is a pre-psychic level, ensuring a human body's vital activity impacting on his/her mental activity; its main function is the movement regulation; the «psyche organism» links are actualised; the study subject at this level is sensory processes; ratio and interval scales are appropriate for empirical data measurements.

2. Psychophysiological level. This level is responsible for the simplest subconscious mental regulations (regulated automated actions such as operations, skills); «psyche - external conditions (environment)» links are actualised; the study subject at this level is sensoryperceptual processes, images, emotions, etc.; the used method of data description (a measurement scale) is an interval scale.

3. Mesopsychic level. This is the level for regulation of involuntary and arbitrary actions. It is a «namely psychological level», characterised by interactions between the conscious and the unconscious, although they are also represented at the second level as structures. At the mesopsychic level, the «psyche - task» links are actualised, and a researcher examines integrative systems (intelligence, motivation, will, etc.). Interval and order scales are appropriate measuring tools.

4. Macropsychological level or the level of individuality substructures (consciousness, sub-consciousness, personal formations). Its function is to regulate activities with «psyche activity» links; the order and classification (nominative) scales are used.

5. The level of a unique personality - an agent of life path, who builds his/her unique life path by regulation of own activities. The way to obtain empirical data at this level is to find similarities (fuzzy classifications are used) and to describe individual cases.

Thus, the highest level of psyche functioning, according to V. M. Druzhinin, is marked by, at least, three following features: 1) a person's uniqueness as his/her ability to produce unique behaviour and creative products; 2) a spontaneous activity as a person's ability to go beyond an actual situation, to regulate own actions and predict future events; 3 ) integrity, which cannot be disunited into elements (holism) due to the subordination of the lower levels to the functioning objective laws and development of this integrity (top-down determination).

The author notes that any of these features is enough to make unsolvable the problem of mental reality measuring. He concludes that «the possibilities to use hermeneutics as a psychological research method become wider as a researcher moves from the lower mental levels to the higher ones. On the contrary, the measuring power of «natural-scientific» psychological methods decreases on this way, which is reflected in the decreased power of interpretations obtained with the objective methods, in particular, with the psychological measuring methods» [4, p. 284]. Therefore, we can conclude that a personality, as the highest vital-cultural and psycho-mental formation, should be examined mainly with qualitative methods.

The article purpose is to systematize scientific ideas and experience of used qualitative methods in personality psychology.

Main material. The qualitative methods should be used at personality research due to the obvious advantages of the so-called psychotechnical cognition that is relevant to the integral mental organization of an individual-personality. According to F. Ye. Vasiliuk, the philosophy of practice used at the psychotechnical (humanitarian) cognition opposes to epistemology, which is characteristic for natural-scientific cognition. The psychotechnical cognition recognizes values 
as being immanent to the cognitive process rather than external to it (natural-scientific cognition). An addressee of the humanitarian cognition is an applied psychologist, not an academic psychologist or specialist in another profession and the subject of such cognition is an interested, involved person, not a neutral, remote one. In this case contacts with a «researched» person are characterized by intensity, uniqueness, emotionality, and it unites the agents of psychotechnical situation. On the contrary, in the design of a natural-science based study, a researcher's contacts with researched people are minimized, standardized, empirically neutral, and reflect links between an agent and an object. As for the cognition process and procedures, the first approach operates with flexible, unique techniques that respond subtly to an experimental situation, while the second one uses rigid, invariable experimental programs and procedures. The knowledge obtained with the psychotechnical approach (a qualitative study based the humanitarian paradigm - Ye. K., R. A.) is internal, personal, «about yourself» or «about you» by its nature. Within the science-oriented paradigm, the obtained result is knowledge in the third person, about «they», and knowledge of a researched person about $\mathrm{him} /$ herself is only factual material. As for a subject and a method, in the first case, the used methods unite the participants of a psychotechnical situation and become themselves the subject of research; and in the second case, the method separates the subject from reality and presents it as an object observed from the outside; with respect to the central subject, then a central subject, for a study of which this method is the optimal, is selected for a practically effective method (in psychotechnical studies), or an adequate research is selected for the central subject method (in natural-scientific psychological research) [2].

According to the definition of A. Straus and J. Corbin, qualitative research in psychology means «any kind of research when data are obtained in non-statistical or quantitative ways» $[10$, c. 16$]$.

The qualitative research purpose, according to N.V. Klyueva, is to reveal the structures of some experience and meaning that a certain object, situation, event or some aspect of a person's own life have for him/her [7, p. 6].

S. Kvale distinguishes the following aspects of qualitative research:

1) striving for profusion and holism of a description;

2) a description by a person of different aspects of is/her life and his/her attitude to them;

3) identification of meanings and their interpretation (what and how?);

4) reliance on contextual analysis;

5) obtaining of qualitative knowledge expressed in everyday language;

6) attention to language as the subject and means for a performed analysis;

7) specificity: descriptions of specific situations, not generalized thoughts; interest in single cases; inductive approach to data;

8) flexibility and lack of rigid standards;

9) reflexivity, openness of a researcher to the new instead of reliance on ready-made categories and schemes of interpretation;

10) focus on specific topics (without a rigid structure or directivity);

11) personal changes during the research; emergence of new meanings; enrichment of experience (new understanding of a situation);

12) importance of interpersonal relationships;

13) preference to the field work [6, p. 6-7].

N.P. Busygina summarizes the methodological foundations of qualitative research, guided by the following criteria: methodological approaches (1); philosophical foundations (2); goals (3); study objects (4); principles of cognition (5); techniques (6) [1, 9]:

1. Deep psychological interpretation: psychoanalysis, variants of «clinical» interpretation on the basis of certain theoretical concepts, etc. (1); the idea of deep hermeneutics (2); interpretations of meanings of some experiences (3); «inner world» understood as a text, containing a «discourse of the unconscious» (4); interpretations of semantic discontinuities as a result of 
unconscious dynamics and reflection on a researcher's theoretical position (5); «symptomatic understanding», interpretation of the text in the light of certain theoretical concepts (6).

2. «A grounded theory» (1); positivism or philosophical hermeneutics and social constructivism (2); creation of the theory of a phenomenon (3); positivist understanding of the phenomenon as having objective meaning; or hermeneutic or constructivist understanding of the phenomenon as meanings obtained through human interactions (4); derivation of a theory from data as a discovery (within the framework of the positive methodology), or creation of a theory as an interpretation (within the framework of the hermeneutic and constructivist methodology) (5); three-stage coding, the method of constant comparisons of data with concepts, strategies of theoretical sampling (6).

3. Conversational analysis (1); the speech act theory, social constructionism (2); understanding of meanings that the conversation participants put into their speech (3); meanings developed during discursive practices, natural speech, conversations (4); analysis of a conversation, with taking into account the context of direct interactions but without wider cultural contexts; orientation directly to the conversation participants' meanings (5); step-by-step descriptive analysis of a conversation course (6).

Qualitative studies are mainly diagnostic, exploratory, verificative or exploratory that can be performed alone or in conjunction with quantitative ones, performed sequentially or in parallel with quantitative ones: 1) qualitative studies leading to a single theory; 2) those that lead to typology; 3) they can be an introduction to a quantitative study; 4) qualitative studies can be used to confirm the findings of quantitative studies; 5) there are studies in which quantitative and qualitative elements are present in the same time; 6) qualitative and quantitative studies can be conducted independently and are considered as complementary [12, p. 78-79].

Data in qualitative studies are accumulated in an open way through unstructured methods, techniques and tools, such as:

- uncontrolled included servations (for example, from the position of a member of the group that he/she observe during its social functioning);

- a free interview with a general plan of questions that is frank, interactive, creative, introspective and dialogue-oriented (individual and group interview);

- analysis of personal documents and activity results (for example, letters, memos), from which it is easy to draw conclusions about personal traits of the studied people and their internal experiences;

- examined cases that testify to a person's unique existential situation in a particular historical or social context;

- the biographical method, focused not only on life facts, but also on identifying by studied people of key existential, turning points of their lives;

- the autobiographical method, presenting an agent's symbolic activity with its understandings, interpretations, durations, which are inevitably subjective;

- the monographic method that characterizes functions of social, educational or cultural institutions;

- the ethnographic method that purpose is to describe the life of a particular group of people with all its cultural aspects;

- phenomenological studies capturing different ways of an individual's perception of phenomena that allow a researcher to explain certain cultural meanings that unite people of a particular culture;

- studies combined with activities that allow a researcher to study social situations to improve them;

- actuating social studies aimed at promotion of significant social changes.

D. O. Khoroshilov substantiated four methodological principles of qualitative research, which were characterized by three criteria: a focus of analysis (1), problems of validity (2), epistemological justification of the principle (3) [11, p. 16-17]: 
1. The principle of contextual sensitivity: analysis of a studied phenomenon with its inclusion into a dialogue, into social, linguistic or cultural environment; this approach is implemented in ethnographic, discursive and cross-cultural qualitative research (1); there are two problem: qualitative research inclusion into the social context and formulation of over-contextual generalizations (2); the contextual principle in psychology - W. James, K. Buhler, L. S. Vygotsky, V. F. Lomov; the contextual principle in qualitative research - D. Silverman, M. Hammersley, N. Denzin, M. Wetherell (3).

2. The principle of understanding: qualitative research is mediated by ancillary analytical categories (or «ideal types»), derived from the empirical data (1); the problem of separation of the «sphere of facts» and the «sphere of personal and value preferences» at formulation of analytical categories (2); the concepts of understanding used in social philosophy (V. Dilthey, M. Weber, G. Simmel); Weber's concept of an ideal type (3).

3. The principle of interpretive reconstruction: an interpretation is a basic way of analytical category formation as a re-designing process (the secondary designing) of subjective values and patterns of human experience (1); the problem of the consistency and coherence of interpretations in qualitative research, as well as the problem of relations between a world designed by a person and its secondary (re-) designing in scientific research (2); «the methodology of interpretations» in the social sciences - K. Geertz, W. Giddens, G.H. Mead, R. Harre, the idea of the first- and second-order constructs (A. Schütz), the idea of mimesis in aesthetics P. Rieker, U. Flick (3).

4. The principle of reflexivity: critical reflection is a tool of qualitative analysis that reveals different semantic positions of a researcher and a respondent (1); the problem of explication of semantic positions as a basis for evaluation of qualitative research validity (2); the philosophy of human consciousness and thinking - M. K. Mamardashvili, A. M. Pyatigorsky, S. L. Rubinshtein (3).

Based on the performed methodological analysis, D.O. Khoroshilov formulated the criteria for qualitative research validity by taking into account the research stages [11, p. 22-23]:

1. The validity criterion for research planning and data collection: a preliminary explication of used theoretical positions, experience in the research area and personal ideas about the examined topic; substantiation of the chosen qualitative approach to the studied problem; validity of sampling, data collection and processing methods; a systematic description of the study («field») context and conditions; a systematic description of the dialogical relations with respondents.

2. The validity criterion for data analysis: reasonableness, logic and coherence of the performed analysis; clear justification of found relations between analytical conclusions and the collected data; delineation of factual descriptions, semantic generalizations and theoretical interpretations for the collected data; reconstruction of all meaningful positions presented in the «raw" data and their adequate representation for readers; stylistic, rhetorical, discursive literacy analyses.

3. The validity criterion for data interpretation: links of theoretical interpretations with analytical categories developed on the basis of the collected «raw» data; presentation in a report of the author's reflective position; social utility and critical potential of the performed analysis; originality and innovativeness of offered interpretations; opportunities for practical implementation of the research.

4. The validity criterion for data presentation: transparency and expressiveness of data presentation; data opened for discussion by the professional community or readers; described reflexive work of the researcher and changes in his/her understanding; assessed possibility of generalizations and social problem solving.

5. The criterion of ethical validity: adherence to the ideas of «open society» and humanism.

The article of the author team presents the requirements for the qualitative research validity in the view of the scientific work structure [8, p. 50-51]: 
1. The introduction states: a) an examined problem and relevance of the topic chosen; b) the research goal, objectives, object and subject; in the case of a methodological work with an illustrative empirical part, a clear separation of methodological and empirical goals, objectives, objects and subjects is required; c) justification of the chosen sample: a sample size in qualitative studies varies from single case to series of interviews, focus groups, or document selection for analysis, but it must guarantee obtainment of consistent trends; the fact must be substantiated that further sample expansion will not lead to fundamentally new results; d) a research hypotheses; hypothesis formulation has its specificity in the case of searching qualitative studies, which purpose is not empirical testing, but empirical generalization: hypotheses in searching qualitative studies are formulated in the form of general statements indicating the areas of research searches, and such hypotheses during research work are not so much tested but complemented, specified, transformed; such research can be performed without hypotheses statement, in this case hypotheses is replaced by research questions or the description of the research logic and principles.

2. The review-theoretical part of the work reveals the main mechanisms and phenomena introduced in the research object and subject, this part contains: a) analytical review of the stated subject topic; c) the analysis of methodological and methodical approaches to the research topic; c) the summary for the theoretical (review-analytical) part with justification of the chosen (developed) strategy for the proposed research.

3The empirical part describes the qualitative research design and planning, presents in detail the study procedure, describes its results and proposes their theoretical discussion.

a) The description of a qualitative research procedure should include: the detailed justification and description of a studied sample; the detailed justification and description of data collection methods and procedures; the description of formal characteristics of the obtained data (a total time of audio or video materials collected from interviews, focus groups, etc.; a number of interview transcripts, average interview volume, etc.); the detailed justification and description of data analysis methods and procedures.

b) The empirical study results are presented in accordance with the rules adopted for the chosen methods: 1) qualitative content analysis; 2) grounded theory; 3) descriptive or interpretative phenomenological analysis; 4) discourse analysis; 5) narrative analysis, etc. The result presentation for any chosen method should be accompanied by quotations or other empirical material supporting the researcher's analysis and conclusions. The report must include the most vivid and characteristic illustrations.

c) The discussion of the obtained results is presented as descriptions (based on the professional terminology) of determined phenomena, their links, mechanisms, etc. with further their interpretation in the context of psychological concepts stated in the theoretical part, as well as in the context of the research goals and objectives.

4. The conclusions should provide meaningful answers to the stated objectives (either confirmed or unconfirmed hypotheses).

5. The research summary, concerning both its empirical and theoretical parts, is presented at the work end.

6. It is obligatory to include literature sources in foreign languages in order to increase the research quality.

7. The annexes should be as complete as possible to present the entire array of raw materials: transcripts, completed forms, interview transcripts, analytical tables and notes, visual material, etc. If it is not possible to presents such data due to their large amount, then the data should be stored and submitted by the evaluating experts' request (in electronic form).

Conclusion. The modern searches for methodological foundations, consistent with the current development of personality psychology at the meta-modern stage, propose to design such scientific research field, where descriptions and explanations, determined patterns and searches for meaning, the nomothetic and idiographic approaches would act not as dichotomies, but as reflected poles, guided by one or another particular research methodology. 
1. Бусыгина, Н. П. (2010). Методологические основания качественных исследований в психологии (автореф. канд. психол. наук). Москва: МГУ.

2. Василюк, Ф. Е. (2003). Методологический анализ в психологии. Москва: МГПУ; Смысл.

3. Дильтей, В. (1996). Описательная психология. Санкт-Петербург.

4. Дружинин, В. Н. (2000). Экспериментальная психология. Санкт-Петербург: Издательство «итер».

5. Карпенко, 3. (2018). Аксіологічна психологія особистості: монографія. 2-ге вид., перероб., доповн. Івано-Франківськ: ДВНЗ «Прикарпатський національний університет імені Василя Стефаника».

6. Квале, С. (2003). Исследовательское интервью. Москва: Смысл.

7. Клюева, Н. В. (2016). Качественные методы исследования: учебно-методическое пособие. Ярославль: ЯрГУ.

8. Мельникова, О. Т., Кричевец, А.Н., Гусев, А.Н., Д.А. Хорошилов, Барский, Ф.И., Бусыгина Н. П. (2014). Критерии оценки качественных исследований. Национальный психологический журнал, 2 (14), $49-51$.

9. Методология качественных исследований в психологии : учеб. пособие (2013). Бусыгина Н. П. (Ред.). Москва: НИЦ Инфра-М.

YPCC.

10. Страусс, А., Корбин, Дж. (2001). Основы качественного исследования. Москва: Эдиториал

11. Хорошилов, Д. А. (2012). Критерии валидности качественного исследования в соичильной психологии. (автореф. канд. психол. наук). Москва: МГУ,

12. Juszczyk, S. (2013). Badania jakościowe w naukach spolecznych. Szkice metodologiczne. Katowice: Wydawnictwo Uniwersytetu Śląskiego.

\section{REFERENCES}

1. Busygina, N. P. (2010). Metodologicheskie osnovaniya kachestvennyh issledovanij $v$ psihologii [Methodological foundations of qualitative research in psychology ] (avtoref. kand. psihol. nauk). Moskva: MGU. (rus.).

2. Vasilyuk, F. E. (2003). Metodologicheskij analiz v psihologii [Methodological analysis in psychology]. Moskva: MGPU; Smysl. (rus.).

3. Dil'tej, V. (1996). Opisatel'naya psihologiya [Descriptive Psychology]. Sankt-Peterburg. (rus.).

4. Druzhynin, V. N. (2000). Eksperimentalnaya psikhologiya [Experimental psychology]. Sankt-Peterburg: Yzdatelstvo «Piter». (rus.).

5. Karpenko, Z. (2018). Aksiolohichna psykholohiia osobystosti: monohrafiia [Axiological psychology of personality: monograph]. 2-he vyd., pererob., dopovn. Ivano-Frankivsk: DVNZ «Prykarpatskyi natsionalnyi universytet imeni Vasylia Stefanyka». (ukr.).

6. Kvale, S. (2003). Issledovatel'skoe interv'yu [Research interview]. Moskva : Smysl. (rus.).

7. Klyueva, N. V. (2016). Kachestvennye metody issledovaniya : uchebno-metodicheskoe posobie [Qualitative research methods: teaching aid]. Yaroslavl': YArGU. (rus.).

8. Mel'nikova, O. T., Krichevec, A.N., Gusev, A.N., D.A. Horoshilov, Barskij, F.I., Busygina N. P. (2014). Kriterii ocenki kachestvennyh issledovanij [Criteria for the validity of a qualitative study in social psychology]. Nacional'nyj psihologicheskij zhurnal [National Psychological Journal], 2 (14), 49-51. (rus.).

9. Metodologiya kachestvennyh issledovanij v psihologii [Methodology of Qualitative Research in Psychology] : ucheb. posobie (2013). Busygina N. P. (Ed.). Moskva : NIC Infra-M. (rus.).

10. Strauss, A., Korbin, Dzh. (2001). Osnovy kachestvennogo issledovaniya [Fundamentals of Qualitative Research]. Moskva : Editorial URSS. (rus.).

11. Horoshilov, D. A. (2012). Kriterii validnosti kachestvennogo issledovaniya v social'noj psihologii [Criteria for the validity of a qualitative study in social psychology]. (avtoref. kand. psihol. nauk). Moskva : MGU. (rus.).

12. Juszczyk, S. (2013). Badania jakościowe w naukach społecznych. Szkice metodologiczne [Qualitative research in social sciences. Methodological sketches]. Katowice: Wydawnictwo Uniwersytetu Śląskiego. (pol.). 


\section{Свген Карпенко, Рафал Абрамцьов ДО ПРОБЛЕМИ ЗАСТОСУВАННЯ ЯКІСНИХ МЕТОДІВ У ПСИХОЛОГІЇ ОСОБИСТОСТІ}

У статті аргументовано історичне протистояння $і$ взаємне доповнення якісних та кількісних методів у психології, відтак здійснено систематизацію важливих методологічних аспектів застосування якісних методів у психології особистості. До їх числа належать: обгрунтування якісних досліджень як найпридатнішої методології цүілісного вивчення людини як особистості з позииій системного підходу; поєднання діагностики $i$ психологічного впливу в процесі діалогічної взаємодії психолога-дослідника $i$ психолога-практика (в одній особі) з клієнтом у процесі діалогічної взаємодії в психотехнічній ситуації; характерні особливості якісних досліджень (холізм, виявлення смислів та їх інтерпретацій, контекстуальність, рефлексивність, інтерактивність, недирективність, індуктивний підхід до даних, ситуативність, увага до одиничних випадків тощьо); види якісних досліджень - діагностичні, експлораційні, верифікаційні або експлораційно-верифікаційні - та варіантів їх поєднання; класифікація методологічних підходів, з яких випливає застосування тих чи тих якісних методів з огляду на їх філософські засади, мету, об'єкт дослідження, принциии пізнання, техніки; методологічні принципи якісних досліджень - концептуальної чутливості, інтерпретативної реконструкиії, рефлексивності; критерї валідності якісних методів з урахуванням етапу (рівневої структури) дослідження - планування $i$ збору даних, їхнього аналізу, інтерпретації даних, їх презентації, етична валідність - та структури підсумкової наукової прачі, підготовленої за результатами якісного дослідження (вимоги до вступу, оглядово-теоретичного розділу кваліфікачійної роботи, ї̈ емпіричної частини, висновків, додатків). Зроблено висновок про релевантність якісних досліджень сучасному етапу розвитку психології особистості епохи метамодерну.

Ключові слова: методологія, психологія особистості, якісні методи (дослідження), валідність якісних досліджень, метамодерн. 